В. Серіков, кандидат педагогічних наук, старший науковий співробітник

Національна академія Служби безпеки України

\title{
ПРОФЕСІЙНІ СКЛАДОВІ ОСВІТНЬОЇ ДІЯЛЬНОСТІ ВИКЛАДАЧІВ ВИЩИХ НАВЧАЛЬНИХ ЗАКЛАДІВ ЗІ СПЕЦИФІЧНИМИ УМОВАМИ НАВЧАННЯ
}

Проаналізовано професійну діяльність викладачів вищих навчальних закладів та виявлено основні педагогічних складові, які забезпечують ефективний процес навчання в різних освітньо-виховних системах. Зосереджено увагу на взаємообумовлених компонентах структури діяльності викладача вищої школи та визначенні його індивідуальних особливостей. Вивчено компоненти професійної діяльності викладачів вищих навчальних закладів зі специфічними умовами навчання, визначено, щзо їхні професійні освітні складові спираються на індивідуально-суб'єктивний характер методів і способів науково-педагогічної діяльності

Ключові слова: прочес навчання; професійна діяльність викладача; компоненти діяльності; педагогічна майстерність; індивідуальні якості

Постановка проблеми. Одним 3 індикаторів високого рівня життя, соціальної та культурної злагоди в суспільстві, інструментом економічного зростання $є$ якісна освіта, яка визнається як на міжнародному так i вітчизняному рівнях. Сьогодні якісні показники розвитку освіти визначають ефективність громадського просування держави в умовах глобалізації світу й підвищення конкурентної боротьби у всіх сферах діяльності людства. Процес модернізації системи освіти України вимагає переосмислення складових вивчення національного і закордонного досвіду підготовки та перепідготовки викладачів для вищих навчальних закладів зі специфічними умовами навчання, підвищення рівня їх професіоналізму в різних освітньо-виховних системах.

У вищій освіті повинні бути задіяні викладачі з високим професійнокваліфікаційним рівнем, які спроможні забезпечити гнучкий, динамічний i ефективний освітній процес та свідому, активну позицію студентів (курсантів та слухачів) у процесі оволодіння обраним фахом.

Викладачу вищого навчального закладу належить стратегічна роль у розвитку особи здобувача освіти, формуванні фахівця і громадянина, тому необхідні додаткові зусилля науковців-теоретиків та практиків у вирішені проблеми удосконалення професійної діяльності науково-педагогічного складу відомчих навчальних закладів.

Проблема професійної діяльності викладачів вищих навчальних закладів зі специфічними умовами навчання $\epsilon$ основною у напрямку дослідження шляхів підвищення якості вищої освіти в вітчизняній та закордонній науці й досить широко розглядається вченими, але дотепер залишається актуальною i недостатньо розробленою. Замало вивчені вимоги до професійної підготовки науково-педагогічного складу в різних освітньо-виховних системах. Ускладнюють цей процес реформування освіти, трансформація пріоритетів та цінностей суспільства, інформаційний та технологічний прогрес. 
Аналіз останніх досліджень i публікацій. Важливим здобутком сучасної науки стало усвідомлення того, що підготовка викладачів до професійної діяльності є складна за своїм змістом і структурою система, функціонування i розвиток якої пов'язані не тільки 3 іiі навколишнім середовищем, а і власними внутрішніми властивостями. Якщо цілі, зміст, норми і критерії, що висуваються педагогічною системою, $є$ зовнішніми об'єктивними чинниками діяльності викладача вищої школи, то вибір методик, технологій i способів науково-педагогічної діяльності $\epsilon$ внутрішніми чинниками цього процесу.

Значних результатів у вивченні професійної діяльності викладачів вищих навчальних закладів досягнуті М. Н. Добрускіним, І. А. Зязюном, 3. Ф. Есаревою, Н. В. Кузьміною, А. І. Кузьмінським, А. Н. Марковою.

Мета статті. Проаналізувати професійну діяльність викладачів вищих навчальних закладів зі специфічними умовами навчання й виявити основні педагогічні складові, які забезпечують процес навчання.

Виклад основного матеріалу. 31998 року в Україні розпочато підготовку викладачів для системи вищої освіти. Нині підготовку магістрів за спеціальністю специфічних категорій 8.000005 "Педагогіка вищої школи" здійснюють 22 вищих навчальних заклади, присвоюючи випускникам кваліфікацію 231 "Викладач університетів та вищих навчальних закладів". Випускники магістратури цієї спеціальності щорічно поповнюють склад педагогічних та науково-педагогічних співробітників вищих навчальних закладів. Це $\epsilon$ доцільним i вчасним напрямом розв'язання проблеми підготовленості на науковій основі викладача до ефективного здійснення саме педагогічної діяльності у всіх вищих навчальних закладах освіти.

Процес навчання у вищих навчальних закладах складається 3 шести основних послідовних етапів: діагностика студентів (курсантів та слухачів), планування, створення умов для реалізації навчального процесу, безпосередня його реалізація, оцінювання результатів навчання, корекція процесу навчання [1].

Орієнтація на навчання впродовж всього життя вимагає від викладачів вищих навчальних закладів зі специфічними умовами навчання формувати у тих, хто здобуває освіту уміння навчатися і розвиватися самостійно за будьяких обставин. Цілком недоречним $\epsilon$ зведення навчання тільки до формальної передачі знань, відпрацювання навичок та формування практичних умінь. На сучасному етапі розвитку освіти викладач втрачає статус одноосібного "утримувача" наукових знань і зростає його роль як партнера, експерта й консультанта, що допомагає студентам (курсантам та слухачам) орієнтуватись у масивах наукової інформації.

Як свідчать дослідження, у зв'язку 3 тим, що процес навчання пов'язаний 3 людським чинником, набуває значущості комунікативностимулюючий компонент професійної діяльності викладача вищої школи. Для його ефективної реалізації викладач вищого навчального закладу повинен сприймати здобувачів вищими освіти такими, якими вони $\epsilon$, це головний мотив педагогічної діяльності; вміти емпатувати вихованцям; бути 
оптимістом; персоніфікувати людину майбутнього; бути творчою людиною тощо. Безумовно, ці якості викладача вищої школи виявляються під час спілкування і це передбачає високий рівень його гуманності [3].

До комунікативних характеристик викладача вищої школи належать здатність поважати і об'єктивно сприймати партнера за спілкуванням і викликати у нього довіру; проявляти чуйність, емпатію в спільній діяльності, прогнозувати й залагоджувати можливі конфлікти; справедливо й тактовно критикувати студентів (курсантів та слухачів), спокійно сприймати i враховувати критику на свою адресу.

Важливим показником стилю спілкування викладача вищої школи $\epsilon$ педагогічний такт, де акумулюються всі складові професійних якостей ї культури особи педагога. Сутність педагогічного такту полягає в дотриманні почуття міри в спілкуванні з вихованцями, в умінні підбирати і застосовувати продуктивний стиль спілкування в педагогічному процесі, в педагогічно доцільному ставленні та коректному впливі викладача вищої школи на тих, хто навчається. К.Д. Ушинський, який володів справжнім педагогічним тактом, писав, що жоден педагог «ніколи не може стати хорошим вихователем-практиком без такту, ...який передбачає приязнь без лицемірства, справедливість без прискіпливості, доброту без слабкості, порядок без педантизму i, головне, постійну розумну діяльність» $[4$, с. $185-$ 194].

Креативно-конструктивний компонент діяльності викладача вищої школи дає можливість мислити, узагальнювати на основі недостатнього числа ознак, створювати нові поєднання, використовуючи наявну інформацію. В основі проектної і конструктивної діяльності лежить здібність до інтелектуальної праці [3].

Організаційна складова діяльності викладача вищої школи включає в себе не лише організацію процесу навчання у вищий школі, але i самоорганізацію викладача. Дослідники виділяють наступні організаторські якості викладача вищої школи: практичність - здатність безпосередньо, швидко і гнучко застосовувати свої знання і свій досвід у вирішенні практичних задач; самостійність, на відміну від навіюваності і сліпого копіювання; спостережливість; схильність до організаторської діяльності; здатність «заряджати» своєю енергією інших людей; здатність знаходити якнайкраще застосування кожній людині; впевненість в собі, витримка; товариськість; наполегливість; активність; працездатність; психологічна вибірковість, здатність розуміти і відповідно реагувати на психологію людей; здатність бачити недоліки у вчинках інших людей - критичність; психологічний такт - здатність встановити міру дії; загальний рівень розвитку як показник кмітливості різниці загальних чуттєвих здібностей людини; ініціативність - творча і виконавча; вимогливість до інших людей; організованість [5].

Діагностичний компонент діяльності викладачів вищих навчальних закладів зі специфічними умовами навчання пов'язаний із дослідженням індивідуально-психологічних особливостей i вихованості студентів 
(курсантів та слухачів), виявленням та визначенням рівня їхньої освіченості й духовності, знань, навичок і вмінь, необхідних для ефективної майбутньої професійної діяльності та відповідності вимогам сучасного суспільства. Для цього викладач вищої школи повинен досконало володіти технологією й процедурою вивчення індивідуально-психічних особливостей тих, хто навчається, умінням робити грунтовний висновок на основі цих досліджень $[3 ; 6]$.

Орієнтовно-прогностична діяльність полягає у виборі викладачем вищої школи конкретних цілей, змісту, методики виховної діяльності, передбачення iii результатів на основі знання рівня індивідуальної підготовленості окремих студентів (курсантів та слухачів), злагодженості та згуртованості колективу навчальних груп. Педагог спочатку ставить діагноз, а потім визначає конкретні орієнтири для формування й розвитку особистості кожного студента і всього колективу в цілому. Характер використаних методів і конкретна методика насамперед залежать від результатів попередніх дій. Ця діяльність потребує від викладача конкретного педагогічного мислення, педагогічної спрямованості, ініціативи, творчості, володіння багатим арсеналом сценаріїв організації виховних заходів і глибоких психологічних та педагогічних знань. Для втілення результатів орієнтовно-прогностичної діяльності необхідна належна організаційна діяльність. Від умілого планування навчально-виховної роботи й визначення оптимальних шляхів іii реалізації, обгрунтованості реальних заходів залежать перебіг педагогічного процесу та його конкретні результати [7].

Підготовка і оцінка реалізованого освітнього процесу потребує від діяльності викладача вищої школи аналітико-оціночної діяльності, зміст якої полягає в аналізі як власних дій, так і дій студентів (курсантів та слухачів), виявленні їх позитивних якостей i недоліків, порівнянні отриманих результатів із запланованими тощо [7]. За допомогою аналітико-оціночної діяльності здійснюється зворотній зв'язок, тобто своєчасно визначаються конкретні результати навчально-виховної роботи й вносяться необхідні корективи у роботу викладача. Цей вид діяльності дуже відповідальний, iii об'єктивність свідчить про професійну зрілість викладача вищої школи.

Всі попередні компоненти діяльності викладачів вищих навчальних закладів функціонують одночасно з основним компонентом - дослідницькотворчим. Вся діяльність педагога базується, організовується, доповнюється і удосконалюється на результатах наукових досліджень. Ефективне втілення всього продукту досягнень наук, які пов'язані з навчальним процесом, можливе тільки за умови творчого ставлення викладача до своєї професійної діяльності. Це має велике значення для освіти й особистісного розвитку студентів (курсантів та слухачів). Творчість викладача - це його мислення i практична діяльність, результатом яких $\epsilon$ створення оригінальних, неповторних цінностей для тих, то навчається встановлення нових фактів, властивостей, закономірностей, а також прогресивні перетворення існуючих методик, технологій, способів навчально-виховної діяльності. Педагогічна творчість одночасно позитивно впливає як на студентів (курсантів та 
слухачів), так i на викладача. Вона сприяє професійному i духовному розвитку, постійному і всебічному вдосконаленню.

До безпосередніх функціональних обов'язків викладача вищого навчального закладу зі специфічними умовами навчання належать такі:

1.Підготовка навчальних курсів, їх методологічне i методичне забезпечення, вибір засобів інформаційної (аудіо, відео, компютерної, телекомунікаційної та ін.) підтримки.

2.Створення навчальних, тренінгових і контролюючих програм, у тому числі комп'ютерних.

3.Авторська участь у підготовці навчальної літератури й навчальнометодичних посібників.

4.Читання лекцій, проведення лабораторних, семінарських та інших практичних занять, конференцій, рольових, ситуаційних і ділових ігор тощо.

5.Організаційно-методичне забезпечення практики студентів (курсантів та слухачів) і участь у її проведенні.

6.Пошук і розробка нових педагогічних методів й освітніх технологій підвищеної ефективності.

7.Консультаційна та інша індивідуальна робота зі студентами (курсантами/слухачами).

8.Пошук джерел фінансування наукових досліджень і споживачів наукових розробок.

9.Планування, організація й виконання наукових досліджень і конкретних практичних розробок.

10.Підготовка наукових, науково-популярних та інших матеріалів.

11.Підготовка розробок, які патентуються.

12.Реалізація виховних функцій у процесі групової та індивідуальної роботи зі студентами (курсантами/слухачами), під час неформального спілкування з ними.

13.Неперервний особистісний i професійний розвиток, підвищення наукової та педагогічної компетентності й кваліфікації.

14.Володіння професійно необхідними практичними навичками та уміннями [8].

Для якісного їх виконання важливу роль відіграють відповідні здібності. Загалом професійні здібності - це сукупність (структура) досить стійких, хоча, звичайно, таких, що змінюються під впливом виховання індивідуальнопсихологічних якостей особистості людини, що на основі компенсації одних властивостей особистості іншими визначає успішність навчання певній трудовій діяльності, виконання іï й можливість вдосконалюватися в ній. Здатності тих, хто навчається в кожний момент - це й передумови їх успішного подальшого професійного навчання, і підсумок всієї попередньої навчальної й трудової діяльності. Професійні здатності розвиваються тільки в професійній діяльності й у спеціальних вправах, розрахованих на формування необхідних для професії особистих якостей [9].

До педагогічних можливо віднести такі здібності викладача вищої школи: емоційна стабільність, чутливість до вихованців; динамічність; 
педагогічно-вольовий вплив на студентів (курсантів та слухачів); здатність робити навчальний матеріал доступним; переконливість, змістовність і яскравість мови; комунікативність; здатність організувати колектив студентів; творчість у роботі; педагогічний такт; спостережливість; педагогічна вимогливість та гносеологічні здібності.

При наявності педагогічних здібностей, педагогічних знань, навичок та вмінь можливо говорити про професійну компетентність, яка $є$ підвалиною професійної майстерності. Взагалі педагогічну майстерність можна визначити як здатність успішно взаємодіяти 3 тими, хто навчається, створювати сприятливі, комфортні психологічні умови в процесі спільної діяльності.

У навчальному процесі психологічна майстерність, на думку Н.В. Кузьміної та М.В. Кухарева, це найвищий рівень психологічної діяльності, який виявляється в тому, що за відведений час педагог досягає оптимальних наслідків у своїй професійній діяльності. Автори розуміють психологічну майстерність як синтез наукових знань, умінь $\mathrm{i}$ навичок педагогічної роботи та комплексу властивостей особистості, що забезпечує високий рівень самоорганізації професійної діяльності на рефлективній основі. Визначають такі складники психологічної майстерності: гуманістична спрямованість діяльності викладача вищої школи; професійна компетентність; педагогічні здібності; психологічна техніка $[10,11]$.

Термін "техніка" часто вживається для сукупної характеристики навичок, умінь і прийомів, які використовують у конкретній сфері діяльності людини.

У зміст поняття "психологічна техніка" включають такі компоненти: перший - це вміння викладача вищої школи керувати психічним станом, проявом соціально-перцептивних здібностей, емоціями та настроєм - як своїм, так і вихованців. Другий - уміння викладача вищої школи впливати на особистість здобувача освіти і на навчальну групу в цілому. Третій стосується технології організації та проведення навчально-виховних заходів. Володіння психологічною технікою свідчить про рівень професіоналізму викладача вищої школи і практично показує його майстерність у педагогічній діяльності.

На думку вчених, в основі педагогічної майстерності лежить педагогічна культура - оволодіння педагогом педагогічним досвідом людства, ступінь його досконалості в педагогічній діяльності, досягнутий рівень розвитку його особистості.

Основними складовими педагогічної культури є наступні:

- педагогічна спрямованість;

- психолого-педагогічна ерудиція;

- гармонія розвинутих інтелектуальних і моральних якостей;

- висока методична майстерність і організованість;

- уміння продуктивно поєднувати навчально-виховну i науководослідницьку діяльність;

- сукупність професійно важливих якостей; 
- педагогічно спрямоване спілкування і поведінка;

- постійне самовдосконалення [7].

Висновки. Для успішного виконання своїх функціональних обов'язків викладач вищого навчального закладу зі специфічними умовами навчання має бути організатором, оратором, аналітиком, науковцем, компетентним фахівцем у галузі предмета кафедри та споріднених навчальних дисциплін, ерудитом в інших галузях знань. Він повинен бути психологом-дослідником і мати для цього відповідні навички та практичні вміння. Окрім цього, така робота потребує високих духовних якостей. Від викладача вимагаються великі розумові, фізичні, часові й емоційно-вольові затрати, він має бути творчою особистістю - це обов'язкова умова підготовки майбутнього творчого фахівця.

До особистісних якостей викладача вищого навчального закладу зі специфічними умовами навчання належать: відповідальність; доброзичливість; об'єктивність; інтерес до життя вихованців; людяність; обов'язковість; порядність; оптимізм; висока моральність; емоційна врівноваженість; самокритичність; патріотизм; релігійність; принциповість; чуйність; емоційна культура і багато інших.

Вивчення всіх компонентів професійної діяльності викладачів вищих навчальних закладів зі специфічними умовами навчання вказує на те, що їхні професійні освітні складові спираються на індивідуально-суб'єктивний характер методів і способів науково-педагогічної діяльності. Саме розвиток, формування і корекція особистісних якостей викладача $є$ одним 3 основних факторів підвищення його педагогічної майстерності.

\section{ЛІТЕРАТУРА}

1. Змеёв С.И. Андрагогика: основы тории и технологии обучения взрослых / С.И.Змеёв. - М. : ПЕР СЭ, 2003. - 207 с.

2. Бондаренко Л.Ю. Изменения в структуре и социальном статусе преподавателей высшей школы / Л.Ю. Бондаренко // СОЦИС. - 2000. - № 10. - 127 с.

3. Добрускин М.Н. Социально-психологический портрет вузовского педагога / М.Н. Добрускин // СОЦИС. - 1995. - №9. - С. 137-141.

4. Уиинский К.Д. О пользе педагогической литературы / К.Д.Ушинский // История дошкольной педагогики в России: Хрестоматия / сост. С.В. Лыков, Л.М. Волобуева; под ред. С.Ф. Егорова. - М., 1999. - 194 с.

5. Уманский Л.И. Личность. Организаторская деятельность. Колектив: избр. труды / Уманский Л.И. - Кострома : КГУ, 2001. - 208 с.

6. Есарева 3.Ф. Особенности деятельности преподавателя высшей школы / З.Ф. Есарева. - Л. : Изд- во Ленинград. ун-та, 1974. - 112 с.

7. Ягупов В.В. Педагогіка : навч. посіб. / В.В.Ягупов. - К. : Либідь, 2002. - 560 с.

8. Кузьмінський А.І. Педагогіка вищої школи : навч. посіб. / А.І. Кузьмінський. - К. : Знання, 2005. $-486 \mathrm{c.}$

9. Платонов К.К., Голубев Г.Г. Психология : підруч. [для студ. вищ. навч. закл.] / К.К. Платонов, Г.Г. Голубев. - М. : Высшая школа, 1977. - 248 с.

10. Кузьмина Н.В. Психологическая структура деятельности учителя / Н.В. Кузьмина, Н.В. Кухарев. - Гомель : Изд-во Гомел. гос. ин-та, 1996. - 57 с. 
11. Педагогічна майстерність : підруч. [для студ. вищ. пед. навч. закл.] / [I.А. Зязюн, Л.В. Крамущенко, І.Ф. Кривонос та ін.] ; заг.ред. І.А. Зязюна. - 2-ге вид., допов. і переробл. - К. : Вища школа, 2004. - 422 с.

В. Сериков, кандидат педагогических наук, старший научный сотрудник

НА Службы безопасности Украины

\title{
ПРОФЕССИОНАЛЬНЫЕ СОСТАВЛЯЮЩИЕ ОБРАЗОВАТЕЛЬНОЙ ДЕЯТЕЛЬНОСТИ ПРЕПОДАВАТЕЛЕЙ ВЫСШИХ УЧЕБНЫХ ЗАВЕДЕНИЙ СО СПЕЦИФИЧЕСКИМИ УСЛОВИЯМИ ОБУЧЕНИЯ
}

\begin{abstract}
Проанализирована профессиональная деятельность преподавателей высших учебных заведений и выявлены психолого-педагогические составляющие, которые обеспечивают эффективный прочесс обучения в разных образовательно-воспитательных системах. Особое внимание уделено изучению взаимообусловленных компонентов структуры деятельности преподавателя высшей школь и определению его индивидуальных особенностей. Изучение всех компонентов профессиональной деятельности преподавателей высших учебных заведений со специфическими условиями обучения указывает на то, что их профессиональные образовательные составляющие опираются на индивидуально-субъективный характер методов и способов научнопедагогической деятельности.
\end{abstract}

ключевые слова: процесс обучения; профессиональная деятельность
преподавателя; $\quad$ компоненты деятельности; педагогическое
индивидуальнье качества.

V. Serikov, Candidate of Pedagogic Sciences, senior research worker

National Academy of Security Service of Ukraine

\section{PROFESSIONAL COMPONENTS OF EDUCATIONAL ACTIVITY OF TEACHERS OF HIGHER EDUCATIONAL ESTABLISHMENTS WITH SPECIFIC CONDITIONS OF TRAINING}

Analyzed professional activity of teachers of higher educational institutions and the identified psychological and pedagogical components, which provide an effective process of learning in different educational systems. Special attention is paid to the study of the interdependent components of the structure activity of the teacher of high school and define its individual characteristics. The study of all components of professional activity of teachers of higher education institutions with specific conditions of the study indicates that their professional educational components are based on individual subjective methods and means of scientific and educational activities.

Key words: process of teaching; professional activity of the teacher; components of activity; pedagogical skills; and individual qualities. 